\title{
BULLYING BEHAVIOR AMONG TEENAGERS AT JUNIOR HIGH SCHOOL LAMPUNG -INDONESIA
}

\author{
Teguh Pribadi ${ }^{1}$, Susri Utami ${ }^{2}$, Marliyana ${ }^{3}$
}

\begin{abstract}
'Lecturer in Faculty of Medicine, Nursing and Health Sciences Malahayati University, Bandar Lampung, Indonesia. Email: teguh@malahayati.ac.id

2Lecturer in Nursing Study Program, Institute of Health Sciences (STIKes) Muhammadiyah Pekajangan

Pekalongan Central Java, Indonesia, email: uutparadisi@yahoo.com

3Lecturer in Diploma in Nursing Baitul Hikmah, Bandar Lampung-Indonesia. Email: marliyana.nafa@yahoo.com
\end{abstract}

\begin{abstract}
Background: Cases of bullying in schools are common at this time. In Junior High School (Sekolah Menengah Pertama 2 Muhammadiyah) Bandar Lampung in 2017 has 16 cases of bullying behavior or about $15 \%$ of cases.

Purpose: Knowing Factors Associated With Bullying Behavior of Junior High School (Sekolah Menengah Pertama 2 Muhammadiyah) Bandar Lampung Year 2018.

Methods: Quantitative research using cross sectional. The participant was 109 students as respondents (total sampling) and obtained 92 respondents as suitable of inclusion criteria. Univariate data analysis to know the frequency distribution and bivariate analysis using chi-square test.

Results: In this study showed the frequency distribution of respondents had low self esteem 38 (84.6\%) behaved bullying, poor family care pattern $44(88 \%)$ bullying behavior, 39 poor peers $39(79,6 \%)$ bullying behavior. the relationship between bullying behavior and self-esteem ( $p$ value 0,000$)$, bullying behavior and family parenting ( $p$ value 0,000 ), bullying behavior and peers group ( $p$ value 0,000 ).

Conclusion: There is a relationship between factors (self esteem, family parenting, and peers) with bullying behavior among students of Junior High School (Sekolah Menengah Pertama 2 Muhammadiyah) Bandar Lampung 2018. Suggest to the highest Education Department of Bandar Lampung, especially through Counseling department to be conducted another research in another school and follow up on the results of this study as: doing school programs that creating networks support, sports, consultants, art, community and antibullying campaigns.
\end{abstract}

\section{Keywords: Self-esteem, family, peers, bullying behavior, adolescents}

\section{INTRODUCTION}

Teenager famously determined as identity seeking ages or trantition age. Its is due to teenagers are on the transition ages from childhood to adolecence. (Feldman, 2008; Tauvan, 2016). The Commission of Child Protection of Indonesia recorded there were downward trend of bullying cases with 159 bullying cases on 2014, 154 cases on 2015, and 97 cases on 2016. However, the number of children with bullying behavior were significantly increased as reported there were 67 cases on 2014, 93 cases on 2015 and reached 112 ceses on 2016. Besides, 40\% students age from 13-15 reported had experience physical abuse by their peer, $75 \%$ students experienced commiting violence in school area, $22 \%$ of female teenagers mentioned that perpretrators of violence in school were teachers and school staffs and 50\% reported bullying at school. (Commission of Child Protection, 2017). The other data showed there were $2.5 \%$ over 1296 students of Junior High School 2 Bandar
Lampung (Department of Education Bandar Lampung, 2017) while 15\% Bullying cases reported from Muhammadiyah Junior High School 2 Bandar Lampung.

The 16 cases of bullying or $15 \%$ which occured at Muhammadiyah Junior High School 2 Bandar Lampung needs higher concern to follow up as the real number might higher than it's recorded since bullying cases tend to be an iceberg phenomenon which may lead to increase of it number from time to time. The further negative effect which are commonly rise up among the victim of the bullying are problems on the teenagers; emotional, academic record and their longterm behaviour that may lead to the condition of low self-esteem, feeling depressed, withdrawal from the society, worried, and feeling of insecure. The other effect of bullying among teenagers related to their school are hate to go to school, absent from school or even drop out. (Astuti, 2008).

The authors were interested to conduct the study at Muhammadiyah Junior School Bandar 
Malahayati International Journal of Nursing and Health Science, Volume 02, No.1, March 2019: 32-40 BULLYING BEHAVIOR AMONG TEENAGERS AT JUNIOR HIGH SCHOOL, LAMPUNG -INDONESIA

Lampung since this school exhibit a good religius status. The Authors asume that a erson with a good religius status will perform a good behaviour and abiding the religion norms and show a good relationship with others in their daily life and tend not to hurt others. Another word to say is a good religius status of person will affect them not to commit bullying in Muhammadiyah Junior High School 2 Bandar Lampung, but the fact showes 16 cases of bullying were occured among 109 students. Based on the interview result to the one of the teachers mentioned that some factors associated to this cases were Self esteem, peers and family. ( Department of Education bandar Lampung, 2017). Based on the introduction and the problems mentioned above, the question of this study is What are the factors associated with bullying behaviour in Muhammadiyah Junior High School bandar Lampung in 2018.

\section{RESEARCH METHODS}

This is a quantitave study with cross sectional design, this study amed to find out the factors associated with bullying behaviour at Muhammadiyah Junior high School. This study were being conducted from March, $5^{\text {th }}$ $17^{\text {th }}$ 2018. The data was analyzed by univariat to see the result by frequency and bivariat analysis by Chi-Square test with $P$ value $\leq a(0.05)$.

\section{RESEARCH RESULTS}

Tabel 1. Distribution of Frequency in school bullying ( $\mathrm{N}=92)$

\begin{tabular}{lcc}
\hline Criteria & $\begin{array}{c}\text { Frequency } \\
(\boldsymbol{F})\end{array}$ & $\begin{array}{c}\text { Persentage } \\
(\%)\end{array}$ \\
\hline Acceptable Bullying & 54 & $58,7 \%$ \\
Unacceptable Bullying & 38 & $41,3 \%$ \\
Total & 92 & $100 \%$ \\
\hline
\end{tabular}

Based on table 1. Most of the respondents $58.7 \%$ had bullying behaviour and $41.3 \%$ had no bullying behaviour from total of 92 respondents.

Tabel 2. Distribution of Frequency in Self Esteem ( $N=92)$

\begin{tabular}{lcc}
\hline Criteria & $\begin{array}{c}\text { Frequency } \\
(\boldsymbol{F})\end{array}$ & $\begin{array}{c}\text { Persentage } \\
(\%)\end{array}$ \\
\hline High & 48 & $52,2 \%$ \\
Low & 44 & $47,8 \%$ \\
Total & 92 & $100 \%$ \\
\hline
\end{tabular}

Based on Tabel 2, Most of the respondent $52.2 \%$ had high self esteem and $47.8 \%$ had low self esteem from total of 92 respondents.

Tabel 3.Distribution of Frequency of The Family Background ( $N=92)$

\begin{tabular}{lcc}
\hline Criteria & $\begin{array}{c}\text { Frequency } \\
(\boldsymbol{F})\end{array}$ & $\begin{array}{c}\text { Persentage } \\
(\%)\end{array}$ \\
\hline Good & 42 & $45,7 \%$ \\
Fair & 50 & $54,3 \%$ \\
Total & 92 & $100 \%$ \\
\hline
\end{tabular}

Teguh Pribadi' Lecturer in Faculty of Medicine, Nursing and Health Sciences Malahayati University, Bandar Lampung, Indonesia. Email: teguh@malahayati.ac.id

Susri Utami ${ }^{2}$ Lecturer in Nursing Study Program, Institute of Health Sciences (STIKes) Muhammadiyah Pekajangan Pekalongan Central Java, Indonesia, email: uutparadisi@yahoo.com

Marliyana ${ }^{3}$ Lecturer in Diploma in Nursing Baitul Hikmah, Bandar Lampung-Indonesia. Email: marliyana.nafa@yahoo.com 
Malahayati International Journal of Nursing and Health Science, Volume 02, No.1, March 2019: 32-40 BULLYING BEHAVIOR AMONG TEENAGERS AT JUNIOR HIGH SCHOOL, LAMPUNG -INDONESIA

Based on table 3, the result showed $54.3 \%$ had fair family background while the rest 45.7 had a good family background.

Tabel 4. Distribution of Frequency of respondent with peer group pressure $(\mathrm{N}=92)$

\begin{tabular}{lcc}
\hline Criteria & $\begin{array}{c}\text { Frequency } \\
(f)\end{array}$ & $\begin{array}{c}\text { Persentage } \\
(\%)\end{array}$ \\
\hline Positive & 43 & $46,7 \%$ \\
Negative & 49 & $53,3 \%$ \\
Total & $\mathbf{9 2}$ & $\mathbf{1 0 0 \%}$ \\
\hline
\end{tabular}

Based on Table 4, most of the respondents $53.3 \%$ had a negative peer group pressure while the rest $46.7 \%$ had a positive peer group pressure. In bivariate analysis describes the relationship of the dependent variable namely bullying behavior with independent variables, namely the factors associated with bullying behavior with the help of computerized statistical tests using Chi Square test with a level of error (a) $5 \%$ then programmed with a computer system using the SPSS for windows program.

Tabel 5. Relationship between self-esteem and bullying ( $N=92)$

\begin{tabular}{|c|c|c|c|c|c|c|c|c|}
\hline \multirow{3}{*}{ Self Esteem } & \multicolumn{4}{|c|}{ Bullying } & \multirow{2}{*}{\multicolumn{2}{|c|}{ Total }} & \multirow{3}{*}{$p$ - value } & \multirow{3}{*}{$\begin{array}{l}\text { OR } \\
\text { (Cl 95\%) }\end{array}$} \\
\hline & \multicolumn{2}{|c|}{$\begin{array}{l}\text { Acceptable } \\
\text { Bullying }\end{array}$} & \multicolumn{2}{|c|}{$\begin{array}{l}\text { Unacceptable } \\
\text { Bullying }\end{array}$} & & & & \\
\hline & $f$ & $\%$ & $f$ & $\%$ & $\mathrm{~N}$ & $\%$ & & \\
\hline High & 16 & $33,3 \%$ & 32 & $66,7 \%$ & 48 & $100 \%$ & & \\
\hline Low & 38 & $84,6 \%$ & 6 & $13,6 \%$ & 44 & $100 \%$ & 0,000 & $\begin{array}{l}2,539 \\
(1,489- \\
3,588)\end{array}$ \\
\hline Total & 54 & $58,7 \%$ & 38 & $41,3 \%$ & 92 & $100 \%$ & & \\
\hline
\end{tabular}

Based on table 5 above, it shows that from 48 respondents who have high self-esteem, 32 (66.7\%) do not behave in bullying and $16(33.3 \%)$ behave in bullying. A total of 44 respondents who had low self-esteem found $38(84.6 \%)$ behaved bullying and $6(13.6 \%)$ did not behave bullying. Based on the results of the statistical test with chi-square the $p$ value is 0,000 . If $p$ value $<a(0,05)$, so that it can be interpreted that there is a significant relationship between self-esteem and bullying behavior in students with an OR value $(2,539)$ which means that low self-esteem has a risk for bullying behavior 2,539 times compared to respondents who have high self-esteem.

Teguh Pribadi' Lecturer in Faculty of Medicine, Nursing and Health Sciences Malahayati University, Bandar Lampung, Indonesia. Email: teguh@malahayati.ac.id

Susri Utami ${ }^{2}$ Lecturer in Nursing Study Program, Institute of Health Sciences (STIKes) Muhammadiyah Pekajangan Pekalongan Central Java, Indonesia, email: uutparadisi@yahoo.com

Marliyana ${ }^{3}$ Lecturer in Diploma in Nursing Baitul Hikmah, Bandar Lampung-Indonesia. Email: marliyana.nafa@yahoo.com 
Malahayati International Journal of Nursing and Health Science, Volume 02, No.1, March 2019: 32-40 BULLYING BEHAVIOR AMONG TEENAGERS AT JUNIOR HIGH SCHOOL, LAMPUNG -INDONESIA

Tabel 6. Family background relationship with school bullying ( $N=92)$

\begin{tabular}{|c|c|c|c|c|c|c|c|c|}
\hline \multirow{3}{*}{$\begin{array}{l}\text { Family } \\
\text { Background }\end{array}$} & \multicolumn{4}{|c|}{ Bullying } & \multirow{3}{*}{ Total } & \multirow[b]{3}{*}{$\%$} & \multirow{3}{*}{$p$-value } & \multirow{3}{*}{$\begin{array}{l}\text { OR } \\
\text { (CI 95\%) }\end{array}$} \\
\hline & \multicolumn{2}{|c|}{$\begin{array}{l}\text { Acceptable } \\
\text { Bullying }\end{array}$} & \multicolumn{2}{|c|}{$\begin{array}{l}\text { Unacceptable } \\
\text { Bullying }\end{array}$} & & & & \\
\hline & $f$ & $\%$ & $f$ & $\%$ & & & & \\
\hline Good & 10 & $23,8 \%$ & 32 & $76,2 \%$ & 42 & $100 \%$ & & \\
\hline Bad & 44 & 88 \% & 6 & $12 \%$ & 50 & $100 \%$ & 0,000 & $\begin{array}{l}3,156 \\
(2,046- \\
4,265)\end{array}$ \\
\hline Total & 54 & $58,7 \%$ & 38 & $41,3 \%$ & 92 & $100 \%$ & & \\
\hline
\end{tabular}

Based on table 6 above, it shows that from 42 respondents who have good families, 32 (76.2\%) do not behave in bullying and $10(23.8 \%)$ behave in bullying. As many as 50 respondents had poor family attitudes, $44(88 \%)$ behaved bullying and $6(12 \%)$ did not behave in bullying. Based on the results of the statistical test with chisquare, the $p$ value was 0,000 . If $p$ value $<a(0.05)$, so that it can be interpreted that there is a significant relationship between families with bullying behavior with an OR value (3.156) which means respondents who have poor family factors have risks for bullying behavior 3.156 times compared to respondents who have good family factors.

Tabel 7. Relationship between peer group pressure and bullying ( $\mathrm{N}=92)$

\begin{tabular}{|c|c|c|c|c|c|c|c|c|}
\hline \multirow{3}{*}{$\begin{array}{l}\text { Peer Group } \\
\text { Pressure }\end{array}$} & \multicolumn{4}{|c|}{ Bullying } & \multirow{2}{*}{\multicolumn{2}{|c|}{ Total }} & \multirow{3}{*}{ p-value } & \multirow{3}{*}{$\begin{array}{l}\text { OR } \\
\text { (Cl 95\%) }\end{array}$} \\
\hline & \multicolumn{2}{|c|}{$\begin{array}{l}\text { Acceptable } \\
\text { Bullying }\end{array}$} & \multicolumn{2}{|c|}{$\begin{array}{l}\text { Unacceptable } \\
\text { Bullying }\end{array}$} & & & & \\
\hline & $f$ & $\%$ & $f$ & $\%$ & $\mathbf{N}$ & $\%$ & & \\
\hline Positive & 15 & $34,9 \%$ & 28 & $65,1 \%$ & 43 & $100 \%$ & & \\
\hline Negative & 39 & $79,6 \%$ & 10 & $20,4 \%$ & 49 & $100 \%$ & 0,000 & $\begin{array}{l}1,985 \\
(1,049- \\
2,921)\end{array}$ \\
\hline Total & 54 & $58,7 \%$ & 38 & $41,3 \%$ & 92 & $100 \%$ & & \\
\hline
\end{tabular}

Based on table 7 above, it shows that from 43 respondents who have good peers, $28(65.1 \%)$ do not behave in bullying and $15(34.9 \%)$ behave in bullying. As many as 49 respondents had peers who were less well found $39(79.6 \%)$ behaved bullying and 10 (20.4\%) did not behave in bullying. Based on the results of the statistical test with chisquare the $p$ value was 0,000 . If $p$ value $<a(0.05)$, so that it can be interpreted that there is a significant relationship between peers with bullying behavior in students with an OR value (1.985) which means that respondents have poor peer factors has a risk for bullying behavior as much as 1,985 times compared to respondents who have good peer factors

Teguh Pribadi' Lecturer in Faculty of Medicine, Nursing and Health Sciences Malahayati University,

Bandar Lampung, Indonesia. Email: teguh@malahayati.ac.id

Susri Utami ${ }^{2}$ Lecturer in Nursing Study Program, Institute of Health Sciences (STIKes) Muhammadiyah Pekajangan

Pekalongan Central Java, Indonesia, email: uutparadisi@yahoo.com

Marliyana ${ }^{3}$ Lecturer in Diploma in Nursing Baitul Hikmah, Bandar Lampung-Indonesia. Email: marliyana.nafa@yahoo.com 
Malahayati International Journal of Nursing and Health Science, Volume 02, No.1, March 2019: 32-40 BULLYING BEHAVIOR AMONG TEENAGERS AT JUNIOR HIGH SCHOOL, LAMPUNG -INDONESIA

\section{DISCUSSION}

The high number of bullying behaviors is the background that in adolescence is the transition stage from childhood to adulthood. As is known, in each phase of development, including in adolescence, individuals have developmental tasks that must be fulfilled. Developmental tasks in adolescence that are accompanied by the development of intellectual capacity, stress and new expectations experienced by adolescents make them susceptible to disorders, both in the form of mental disorders, behavioral disorders, as well as feeling disorders such as stress, sadness, anxiety, loneliness, and doubts in adolescents that make them take risks by committing delinquency and behaving aggressively. And one of the aggressive behaviors that often occurs in adolescents is bullying behavior (Cullingford \& Morrison, 1995; Tauvan, 2016). While adolescents who do not behave in bullying in the background of high moral understanding will first think of what they will do. The thought is whether the deed will be an act that is said to be of good or bad value. The existence of a child's moral understanding can result in children having the ability to assess bullying actions that hurt others as actual bad actions that should not be done, so that children with high moral understanding do not engage in bullying behavior. Where as children who lack moral understanding do not think about each action whether it contains good or bad values. The child does not want to know whether his actions will hurt his friend or not. As a result, these children have a tendency to do bullying behavior (Wiyani, 2012). According to the analysis of researchers, the high number of bullying is caused by several characteristics of respondents who support respondents to behave bullying. The results of this study found that of 92 respondents, $77(78.3 \%)$ were male. With the number of respondents dominated by male students, it is not surprising to find that more than half of the respondents behave bullying. (Santrock, 2012; Surilena, 2016) states that male adolescents are more likely to engage in aggressive behavior and delinquency than adolescent girls. Bullying and victimization are more common in boys. For teenage boys, being "strong" and "masculine" are traits related to high status. These characteristics are often measured by their success in committing delinquency and escaping their punishment.

\section{Self esteem}

Unlike teenagers who have high self-esteem, the teenager has a sense of confidence that makes the teenager's condition not ashamed to connect with other people, not ashamed to appear in public without withdrawing or being quiet and lazy to joke. Students who are identified as victims of bullying have a significant decrease in global self esteem and feelings of inadequacy than students identified as pure bullying. Self-esteem is also the most important key in forming a person's behavior because it can influence the thought process, decisions taken, and values of individual goals (Santrock, 2012; Wilda, 2016).

This high self-esteem is in line with previous research explaining that someone who has high self-esteem is able to accept his existence and acknowledge his abilities. Adolescents become able to distinguish between good deeds and bad deeds and maintain behavior so as not to harm others (Erniati \& Mamnu'ah, 2017).

According to the analysis of researchers, more bully behavior has lower self-esteem compared to respondents who have high self-esteem. A person who has low self-esteem will see himself as a worthless person. This feeling of worthlessness can be reflected in a sense of uselessness and lack of ability both in terms of academics, social interaction, family and physical condition. Low selfesteem can make a person feel unable to establish contact with his own friends so that he becomes irritable and angry. As a result the child will do something that hurts his friend.

\section{Family}

Families that are not good are based on families that have their own duties and functions, if their duties and functions are not carried out properly, there will be an imbalance between family members which sometimes triggers conflict. One family member who does not understand even does not perform his duties and responsibilities properly, then the family will experience disruption in the course of family life (Honggowiyono, 2015). While a good family can be said to be harmonious / good, that is if the family understands and understands their duties, functions and

Teguh Pribadi' Lecturer in Faculty of Medicine, Nursing and Health Sciences Malahayati University,

Bandar Lampung, Indonesia. Email: teguh@malahayati.ac.id

Susri Utami ${ }^{2}$ Lecturer in Nursing Study Program, Institute of Health Sciences (STIKes) Muhammadiyah Pekajangan Pekalongan Central Java, Indonesia, email: uutparadisi@yahoo.com

Marliyana ${ }^{3}$ Lecturer in Diploma in Nursing Baitul Hikmah, Bandar Lampung-Indonesia. Email: marliyana.nafa@yahoo.com 
responsibilities. Good and true education in the family will greatly influence the development of children, both in terms of mental, attitudes, and personality of the child. Parents in living their daily lives must be able to provide a good example, because a child easily imitates the attitudes or words made by people around him (Lestari, 2012).

Researchers analyzed that, adolescents who behave in bullying in schools tend to have families who are role models for bullying behavior. Like the bad habits of parents who often fight in front of children and lack of attention and affection from parents to children. This causes children to learn to be aggressive by observing interactions that occur within the family every day. Parents who often fight or fight tend to form children who are at risk of becoming more aggressive. The use of violence and excessive action in disciplining children by parents, caregivers, and teachers indirectly encourages bullying behavior in their environment.

\section{Peer}

Peers who are not good are based on associations that are used to committing violence and associating with children who like violence, the negative influence of social interaction in friendship, which is very close to deviant behavior, namely juvenile delinquency which causes a lack of good peers. Teenagers who tend to hang out with their peers who often get drunk and use drugs will be very ranges to follow their lifestyle. Although it has not been stated absolute that the teenager will follow the lifestyle of his friends but needs to be aware that adolescence is instability, both in thinking and holding the principle of life. (Papalia, Olds \& Feldman, 2008). Siswati and Costrie Ganes Widayanti revealed that some of the responses shown by subjects who were victims of bullying were influenced by the experience and learning process carried out by the subject so that the subject would react to the bullying behavior carried out by his friends (Wiyani, 2012). Bullying behavior can also be influenced by associations of peers who are used to bullying and associating with children who like violence (Priyatna, 2010). According to Elliot, 2002 in Wilda, 2016 one of the factors that influence bullying behavior in adolescents is peers. Negative influences given by peers can have an impact on aggressive behavior in adolescents, adolescents tend to commit violence to others because it is influenced by peers who also do the same thing, it is done by teens so that teens can be valued and accepted as friends by their peers. Researchers analyzed that, the tendency of adolescents to behave in bullying was due to the need for adolescents to remain accepted in their peer groups. This makes teenagers inevitably have to adjust to the norms that apply in the group. So that teens will imitate the habits that are done by group members both positive and negative. There are various ways to adjust. Students tend to do conformity with their classmates to feel comfortable in participating in daily class activities. The behavior emulated by students is positive or negative. One potential negative behavior to be imitated by students is bullying. If the number of students is bullying a lot, or bullying is done by students who are influential in class, then other students are likely to participate in bullying as well, or at least consider bullying as normal. The more often teenagers bulge and bully, the lower their self-esteem (Elliot, 2002; Wilda, 2016). Aspects of self-esteem according to Coopersmith are the process of learning, appreciation, acceptance, and interaction with the environment. Self-esteem is the most important key in forming a person's behavior because this self-esteem can influence the thinking process, decisions taken, and values of individual goals (Apsari, 2013; Fithria \& Auli, 2016). Teenagers who have high self esteem will have low bullying behavior. This is because adolescents with high self esteem will feel satisfied with what they have, resulting in an attitude of confidence, pride, feeling strong, and feeling useful. In addition, with high self esteem, someone will tend to focus on the strengths or strengths they have and be able to remember pleasant events that will help the individual to maintain a positive evaluation of himself and direct things and positive behavior (Baron \& Byrne, 2012; Zainap, 2017).

While individuals with low self esteem are more easily expressing their anger openly so that they will maintain their negative evaluation. Low self esteem will encourage individuals into excessive feelings of inferiority due to self actualization that cannot be fulfilled so that someone will struggle to achieve personal interests, set high and unrealistic goals which then make the impulse of aggression appear to protect their fragile self-esteem so that

Teguh Pribadi' Lecturer in Faculty of Medicine, Nursing and Health Sciences Malahayati University,

Bandar Lampung, Indonesia. Email: teguh@malahayati.ac.id

Susri Utami ${ }^{2}$ Lecturer in Nursing Study Program, Institute of Health Sciences (STIKes) Muhammadiyah Pekajangan Pekalongan Central Java, Indonesia, email: uutparadisi@yahoo.com

Marliyana ${ }^{3}$ Lecturer in Diploma in Nursing Baitul Hikmah, Bandar Lampung-Indonesia. Email: marliyana.nafa@yahoo.com 
aggression is carried out to form a depreciation reaction that is the tendency to assess the achievements of others and consider what is achieved by themselves, besides that it can be in the form of indictment by blaming / pressing others to reciprocate others in order to protect their weak self esteem (Feist \& Feist, 2012 in Zainap, 2017).

High self-esteem that behaves bullying raised by the perpetrator is not accompanied by high moral understanding. This is what causes a teenager to behave in bullying. Moral understanding emphasizes the reason why an action is done, not just the meaning of an action so that it can be assessed whether the action is good or bad, but about how someone thinks up to the decision that something is good or bad. Children with high moral understanding will first think of what they will do. The thought is whether the deed will be an act that is said to be of good or bad value. The existence of a child's moral understanding can result in children having the ability to assess bullying actions that hurt others as actual bad actions that should not be done, so that children with high moral understanding do not engage in bullying behavior.

Whereas children who lack moral understanding do not think about each action whether it contains good or bad values. The child does not want to know whether his actions will hurt his friend or not. As a result the child has a tendency to carry out bullying behavior (Widiharto, 2011; Wilda, 2016). Low self-esteem can make a child feel unable to establish a relationship with his friend so that he becomes irritable and angry. As a result the child will do something that hurts his friend. One of the factors to reduce the possibility or prevention so as not to be targeted by bullying is the factor of self-esteem. Teenagers cultivate good self-esteem because of good self-esteem, will behave and think positively, appreciate themselves, respect others, be confident, optimistic, and dare to say their rights. Individuals with high self-esteem tend to bring positive impacts to others in their environment such as not doing harm to others such as bullying. There are still many teenagers from among good families but still behave in bullying, this is based on parents or families acting as informants. Informants as parents are also aware of the bullying behavior of their children. But the informants still did not know how to prevent bullying behavior for their children (Chakrawati, 2015). The thing that must be emphasized and practiced is empathy in family relationships, between parents and children, and between siblings. Informants are parents, the process of family communication that occurs causing the bullying behavior.

Though family communication is the main and first foundation to save children from this bullying behavior (Lesatari, 2012). According to (Nwokolo \& Efobi, 2014; Wilda, 2016), bullying behavior develops from a continuous process of interaction with the home or family environment as its base. According to him, unwanted behavior such as bullying is the result of the dynamics of interactions that occur in the family. Unlike the case with teenagers who have poor families but do not behave bullying, this is motivated by a family that is not harmonious. Adolescents who do not do bullying can be influenced by factors instilled in school about religion, the life of a believer seriously in carrying out the commands of religion rather than the lives of people who are indifferent to the commands of the religion they adhere to, on the faces of religiously devoted people. , his attitudes and actions do not suffer other people, other than people who are separated from their religious ropes, their lives will be easily disturbed by the shock of the soul and atmosphere (Desmita, 2015). Observing this opinion, bullying actors are classified as someone who has been disturbed by the shock of the soul and atmosphere, this is evidenced by their behavior that harms others regardless of the factors that influence the behavior. On the other hand, someone who is strong in faith, then that person will not easily carry out deviant actions including bullying (Wilda, 2016). Children who grow up in aggressive and abusive families will imitate these habits in their daily lives.

Physical and verbal violence by parents to children will be an example of behavior that can make the child imitate the behavior of his parents (Priyatna, 2010). A study of aggressive and antisocial behavior in children conducted by Wolf (1985) found that there are several aspects in family factors that have a relationship with aggression in adolescents, namely the absence of fathers in the family, loss of parents due to divorce or death, mothers who are depressed, easily offended parents' personality, low socio-economic

Teguh Pribadi' Lecturer in Faculty of Medicine, Nursing and Health Sciences Malahayati University,

Bandar Lampung, Indonesia. Email: teguh@malahayati.ac.id

Susri Utami ${ }^{2}$ Lecturer in Nursing Study Program, Institute of Health Sciences (STIKes) Muhammadiyah Pekajangan Pekalongan Central Java, Indonesia, email: uutparadisi@yahoo.com

Marliyana ${ }^{3}$ Lecturer in Diploma in Nursing Baitul Hikmah, Bandar Lampung-Indonesia. Email: marliyana.nafa@yahoo.com 
class and large family size (Elliot, 2002; Wilda, 2016). Researchers analyzed that, adolescents who behave in bullying in schools tend to have families who are role models for bullying behavior. Like the bad habits of parents who often fight in front of children and lack of attention and affection from parents to children. This causes children to learn to be aggressive by observing interactions that occur within the family every day. Parents who often fight or fight tend to form children who are at risk of becoming more aggressive. The use of violence and excessive action in disciplining children by parents, caregivers, and teachers indirectly encourages bullying behavior in their environment. The family is the closest environment to raising and maturing children, in which children get their first education. Therefore, the family has an important role in the development of children, a good family will have a positive effect on children's development, while a poor family will have a negative effect. The high level of peer factors is still good, but the teenagers still behave in bullying. This is motivated by the perpetrators not accompanied by high moral understanding. This is what causes a teenager to behave in bullying. Moral understanding emphasizes the reason why an action is carried out, not just the meaning of an action so that it can be assessed whether the action is good or bad, but about how someone thinks up to the decision that something is good or bad (Yusuf \& Juntika, 2011). The behavior emulated by students is positive or negative. One potential negative behavior to be imitated by students is bullying. If the number of students doing bullying is large, or bullying is done by influential students in the class, then other students are likely to participate in bullying too, or at least consider bullying as a natural thing (a positive attitude towards bullying) (Gillete \& Daniels, 2009). While adolescents have good friends but still do bullying, adolescents do not have a moral understanding, do not think about each action whether it contains good or bad values. The teenager does not want to know whether his actions will hurt his friend or not. As a result, these adolescents have a tendency to carry out bullying behavior (Widyastuti, 2014). Bullying behavior can also be influenced by associations of peers who are used to bullying and associating with children who like violence. Peers play a very important role in the development and confirmation of bladder behavior and anti-social attitudes among adolescents. Peer attendance as an observer, indirectly, helps the counselor gain power support, popularity, and status. In many cases, witnesses or peers who see, generally take an attitude of silence and do not want to intervene (Priyatna, 2010).

Researchers analyze that one of the causes of a teenager being affected by bullying behavior is because of the large influence of peers and the need for adolescents to adapt to the rules and habits that apply in the environment and the people around them. This is what makes teenagers inevitably have to adjust to their peers and also participate in bullying behavior. Relationships that occur are negative, where if the influence of peers is good then the bullying behavior that occurs is low and if peer influence is not good then the bullying behavior that occurs is high. School friends are a significant group for teens because most of the time is spent in school with school friends. Children when interacting in school and with friends around the house are sometimes encouraged to do bullying. Sometimes some children bullying other children in an attempt to prove that they can belong to a certain group, even though they themselves feel uncomfortable with the behavior.

\section{CONCLUSION}

Based on statistical analysis tested by Chi square revealed $p$ value 0.000 , which is smaller than alpha 0.05 thus, it can be concluded there was relationship between self-esteem, family and peer with the bullying behavior among students in Junior High School 2 Muhammadiyah Bandar Lampung in the year of 2018 .

\section{REFERECES}

Astuti, P. R. (2008). Meredam Bullying 3 Cara Efektif Meredam K. P. A. (Kekerasan Pada Anak). Jakarta: Grasindo.

Chakrawati, F. (2015). Bullying Siapa Takut?. Solo: PT. Tiga Serangkai Pustaka Mandiri.

Desmita, R. (2015). Psikologi Perkembangan. Bandung: PT.Remaja Rosdakarya. Diakses : www.ucarecdn.com

Teguh Pribadi' Lecturer in Faculty of Medicine, Nursing and Health Sciences Malahayati University,

Bandar Lampung, Indonesia. Email: teguh@malahayati.ac.id

Susri Utami ${ }^{2}$ Lecturer in Nursing Study Program, Institute of Health Sciences (STIKes) Muhammadiyah Pekajangan Pekalongan Central Java, Indonesia, email: uutparadisi@yahoo.com

Marliyana ${ }^{3}$ Lecturer in Diploma in Nursing Baitul Hikmah, Bandar Lampung-Indonesia. Email: marliyana.nafa@yahoo.com 
Malahayati International Journal of Nursing and Health Science, Volume 02, No.1, March 2019: 32-40 BULLYING BEHAVIOR AMONG TEENAGERS AT JUNIOR HIGH SCHOOL, LAMPUNG -INDONESIA

Dinas Pendidikan Kota Bandar Lampung.(2017). Laporan Data Siswa Bermasalah di MTs N 2 Bandar Lampung.

Dinas Pendidikan Kota Bandar Lampung.(2017). Laporan Data Siswa Bermasalah di SMP Muhammadiyah 2 Bandar Lampung.

Erniati, W., \& Mamnu'ah, M. A. (2017). Hubungan Harga Diri Dengan Perilaku Bullying Pada Remaja Di Smp Muhammadiyah 2 Gamping Sleman Yogyakarta.(Doctoral dissertation, Universitas' Aisyiyah Yogyakarta).

Gillette, P \& Daniels, D. (2009). Bullying At School and Online. American: Holding Inc

Honggowiyono, P. (2015). Pertumbuhan dan Perkembangan Peserta Didik. Malang: Gunung Samudera.

Komisi Perlindungan Anak Indonesia. (2017). Rincian Tabel Data Kasus Pengaduan Anak Berdasarkan Klaster Perlindungan Anak.Jakarta: Komisi Perlindungan Anak.

Lestari, S. (2012). Psikologi Keluarga (Penanaman Nilai dan Penanganan Konflik dalam Keluarga. Jakarta: Kharisma Putra Utama.

Papalia, Olds \& Feldman (2008). Human development (psikologi perkembangan) bagian $v$ s/d ix: masa remaja, masa dewasa awal, masa dewasa pertengahan, masa dewasa akhir, akhir sebuah kehidupan. ed.9th. Jakarta: Penerbit Kencana Prenada Media Group.
Priyatna, A. (2010). Let's End Bullying. Jakarta : PT. Elex Media Komputerindo, Gramedia.

Surilena. (2016). Perilaku Bullying (Perundingan) Pada Anak dan Remaja. Vol 43.No. 1. Jurnal Psikiatri. Fakultas Kedokteran. Universitas Katolik Atma Jaya

Tauvan, H. (2016). Hubungan Antara Regulasi Emosi Dan Kontrol Diri Dengan Perilaku Bullying. Jurnal. Fakultas Psikologi.Universitas Pendidikan Indonesia.

Wilda, F. (2016). Faktor-Faktor Yang Berhubungan Dengan Perilaku Bullying Pada Siswa SMKN 1 Padang Tahun 2016.Jurnal.Fakultas Keperawatan. Universitas Andalas.

Wiyani, A. (2012). Save Our Children From School Bullying. Jogjakarta : Arruzz Media.

Yusuf, S \& Juntika, N. (2011). Teori Kepribadian. Bandung: PT. Remaja Rosdakarya Offset.

Zainap, H. (2017). Perilaku Bullying Pada Ramaja Di Tinjau Dari Self Esteem dan Jenis Kelamin. Jurnal. Fakultas Psikologi. Universitas Muhammadiyah Surakarta.

Widyastuti, Y. (2014). Psikologi Sosial.Yogyakarta : Graha IImu.

Teguh Pribadi' Lecturer in Faculty of Medicine, Nursing and Health Sciences Malahayati University,

Bandar Lampung, Indonesia. Email: teguh@malahayati.ac.id

Susri Utami ${ }^{2}$ Lecturer in Nursing Study Program, Institute of Health Sciences (STIKes) Muhammadiyah Pekajangan

Pekalongan Central Java, Indonesia, email: uutparadisi@yahoo.com

Marliyana ${ }^{3}$ Lecturer in Diploma in Nursing Baitul Hikmah, Bandar Lampung-Indonesia. Email: marliyana.nafa@yahoo.com 